\title{
Erosion Control at Construction Sites: The Science-Policy Gap
}

MARTIN M. KAUFMAN

Earth and Resource Science Department

516 Murchie Science Bldg.

University of Michigan-Flint

Flint, Michigan 48502-1950, USA

ABSTRACT / To test the effectiveness of Michigan's soil erosion control law, 30 construction sites were evaluated in the east-central part of the state. The analytical framework lumped nine best management practices (BMPs) most closely related to the law into three categories: slope stabilization, soil stabilization, and water management. All sites were in the land clearing or foundation/framing stage of construction and were evaluated within 2 days after a rainfall event. Only four of the sites performed above the mean of the scoring scale, with the categorical scoring of BMPs indicating the worst performance for slope stabilization measures. The poor results suggest a failure to integrate scientific knowledge of erosion control with policy. A fundamental problem is the lack of basic site data on soil, topography, and hydrology, resulting in the incorrect application of BMPs, such as staging, filter fences, and berms. The current institutional framework for soil erosion control also provides disincentives to mitigate local erosion problems.
Soil erosion and stream sedimentation are persistent problems in and around construction sites. Though minor compared to cropland in terms of total sediment yield for the U nited States as a whole, individual construction sites can contribute massive loads of sediment to small areas in short time periods. Although soil loss rates have generally declined in most construction areas since Wolman and Schick (1967) reported loss rates over 100,000 tons/ $\mathrm{mi}^{2} /$ year, many modern construction sites suffer substantial loss rates despite regulation.

The effects of soil erosion and sedimentation on streams, lakes, and wetlands are well documented ( Graf 1975, Booth 1990). These impacts are expensive in terms of dollar costs and aesthetic costs (Pimentel and others 1995). Sediment is widely considered the principal pollutant in our water systems, a point explicitly recognized in the Clean Water Acts (CWAs) enacted in 1972 and the Food Security Act of 1985. The Food Security Act established a Conservation Reserve Program, providing an opportunity for farmers to enter into 10-year contracts with the Department of Agriculture to take highly erodible land out of production and receive annual rental payments for returning the land to permanent vegetative cover.

In the 1987 reauthorization of the CWA all states were required to conduct an assessment of nonpoint sources and develop mitigation strategies. The state of Michigan responded quickly and in 1987 conducted an assessment of nonpoint sources. In 1988, a mitigation

KEY WORDS: Urban erosion control; Best management practices; Construction sites; Erosion control framework; Sciencepolicy gap plan was developed, which promoted the identification of nonpoint pollution sources at the watershed level, and the implementation of best management practices (BMPs) (MDNR 1988). BM Ps are structural, vegetative, or managerial practices used to treat, prevent, or reduce water pollution. In 1992, a revised version of the 1987 BMP list was prepared with yearly updates (MDEQ 1992).

Erosion control procedures in Michigan are governed by the Soil Erosion and Sedimentation Control Act (SESCA) of 1972 (MCLA 1998). Enforcement of this erosion law is provided by local enforcing agents (LEAs) at the county level, or by communities if local resources and expertise are available. A community creates a local soil erosion control ordinance by adopting the SESCA "by reference."

For the United States, trends in governmental control of erosion and sedimentation in urbanizing areas has been documented by Mertes (1989). Specific erosion control measures at construction sites have also been evaluated (Scheuler and Lugbill 1989, Horner and others 1990, Knowen 1990, Barrett and others 1995a, 1995b, 1998). This paper presents an analytical evaluation of multiple erosion control methods used at active construction sites in urbanizing areas. The primary objectives are to assess the collective effectiveness of the erosion control measures employed and to determine the characteristics of the observed erosion control performance.

\section{Study Area}

The study area consists of five counties in east-central Michigan (Figure 1). These counties are experiencing 


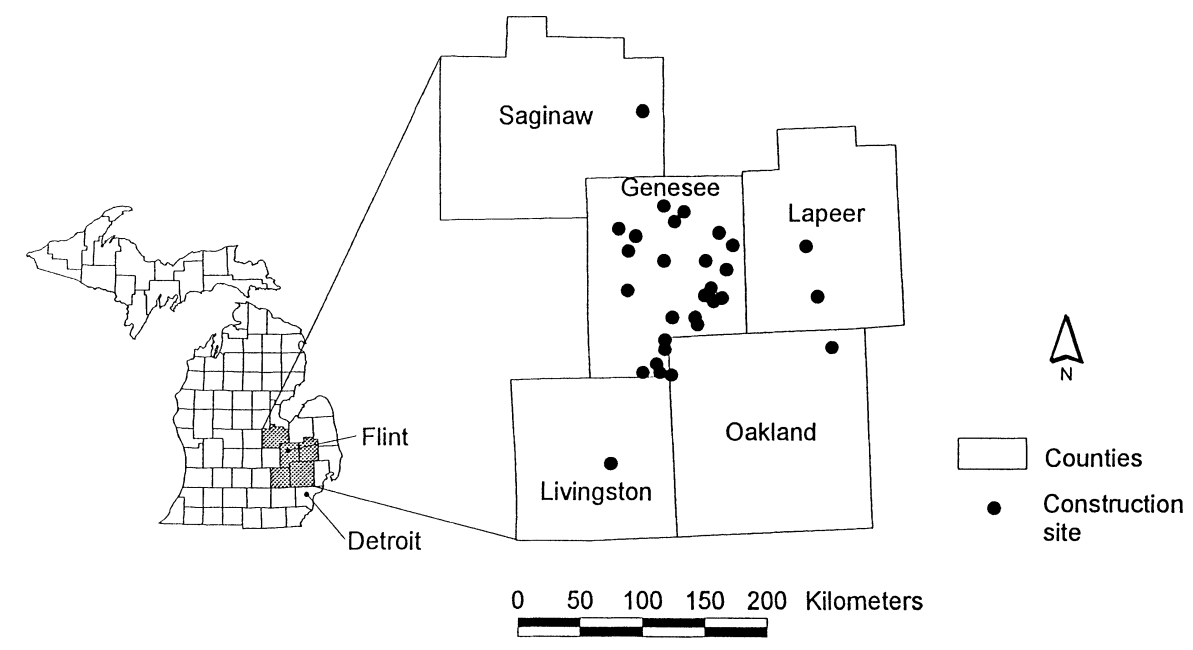

Figure 1. Study area.

rapid growth on the urban-rural fringes of Detroit and Flint, and all contain numerous commercial and residential construction sites at various stages of completion. This area has an abundance of small-scale water features that are attractive to developers but also highly vulnerable to sedimentation from even small construction sites. In Oakland County, for example, there are over 300 lakes and even more wetlands.

Southern Michigan is dominated by glacial terrain formed during the retreat of the late Wisconsinan ice sheet 10,000 to 15,000 years B.P. The region is crossed by several systems of moraines and related land forms containing thousands of topographic depressions in which lakes and wetlands have formed. These features are generally small, and as a whole, the landscape exhibits high local diversity.

Soils in the region are understandably varied, ranging from sandy loams on outwash plains to finer textures on moraines and lake plains. Infiltration capacities and permeability rates tend to vary with soil texture, and where soils are stripped of vegetative cover, most are capable of yielding high rates of runoff in all seasons. Where ground water lies close to the surface around many lakes and wetlands, infiltration capacities can be very low, especially in winter and spring, and runoff rates correspondingly high. These are favorite development sites, and they are especially prone to high soil erosion rates (Earle 1972, Engel 1977, Feenstra 1982, H olcomb 1993, laquinta 1994).

Gross water balance in the region is strongly positive, with a surplus of soil moisture during spring and fall. Precipitation averages $76.2-81.3 \mathrm{~cm}$ (30-32 inches) per year, with an average yearly lake evaporation of 61.0$71.1 \mathrm{~cm}$ (24-28 inches). Runoff can be substantial in any season, but most events of record have occurred in spring when heavy rainfall combines with wet soils and sometimes snowmelt to produce massive runoff. Summers typically produce one or two runoff events from thunderstorms at most sites, although these storms are substantially smaller than those of similar frequency and duration in the southern United States. Winter runoff from rainfall and snowmelt tends to be of long duration and relatively low magnitudes, but can be substantial owing to high soil moisture and seasonally elevated water tables.

Ground water in the glacial drift varies with topographic elevation. In some areas as much as one-third of the land is at or below the water table for 4-6 months a year. In areas of higher elevations, the drift aquifer may be more than $60 \mathrm{~m}$ (200 feet) deep, especially in highly permeable deposits. Near-surface water table elevations are common near the edges of the lakes and wetlands. Within drainage basins, these wetlands and other surface features, such as swales, wooded hillslopes, and flood plains, provide sinks for fugitive sediment.

Figure 2 shows a small section of the study area exhibiting closed (A), partially closed (B), and open sinks (C). Closed sinks (e.g., some wetlands) are typically small depressions, such as glacial kettles that trap sediment and prevent its transport through the watershed. Partially closed sinks, such as swales, trap sediment and then release all or part of it to other parts of the watershed. Flood plains and woodlands are open sinks, and they store sediment for varying time periods before the sediment is moved within the drainage net, while other sediment may pass through the watershed if it is entrained as suspended load in a stream. These sink systems are discussed later, as they have implications for controlling the impacts from construction site erosion. 


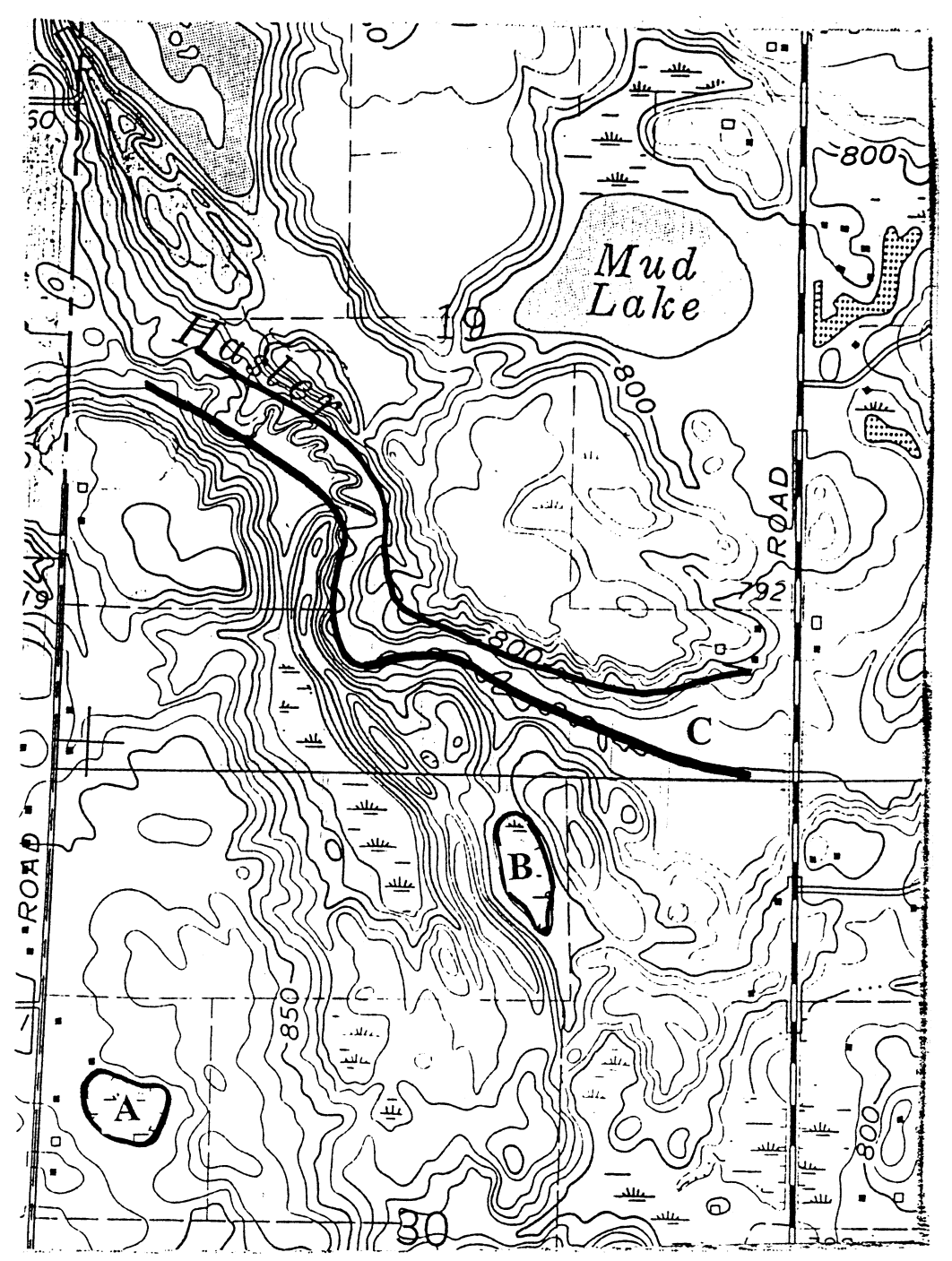

Source: United States Geological Survey, 1980. 7.5 Minute Quadrangle, Elba, MI.

$\begin{array}{lllllll}0 & 0.1 & 0.2 & 0.3 & 0.4 & 0.5 & \text { Kilometers }\end{array}$

Figure 2. Sediment sinks.

\section{Methods}

The implementation of the SESCA is assessed in this study by evaluating the BMPs most closely related to the law. For instance, the law requires the construction site "earth change" to "limit the water flow to a non-erosive velocity." This guideline was translated into the general category of water management, with its associated BM Ps of buffer strip, filter fence, and sediment basin. The final evaluation framework created three general catego- ries from the SESCA requirements, and resulted in a total of nine associated BMPs (Table 1).

\section{Site Selection}

A balanced sample of construction sites was employed to capture the widest possible variation of erosion control measures. Of the 30 sites examined, 13 were commercial, with 5 in land clearing and 8 in the foundation/framing stage. The remaining 17 were 
Table 1. Erosion control best management practices by category

\begin{tabular}{lcc}
\hline Slope stabilization & Soil stabilization & Water management \\
\hline Mulching & Grading & Buffer strip \\
Seeding & Access road & Filter fence \\
Staging & Spoil piles & Sediment basin \\
\hline
\end{tabular}

residential, with 9 in land clearing and 8 in the foundation/ framing stage. To ensure that sites would meet the minimum area requirement for inclusion under the jurisdiction of SESCA, all selected sites had an area over 0.45 ha ( 1 acre).

\section{Evaluation}

The performance of the nine BMPs listed in Table 1 was assessed at each site shown in Figure 1. Four guidelines outlined in MDEQ (1992) were followed when assigning scores. These consisted of: land use compatibility; restrictions due to soil/ topography/ climate; when to apply; and where to apply the BMPs. A value of 1 was assigned to measures that were present during the specified phase, properly located in terms of soil, topography, climatic conditions, and site locationand functioning. A zero indicated a measure was present but improperly timed, located, or not functioning; and $a-1$ indicated the measure was absent when it should have been present under the given criteria. The scaling from -1 to +1 was used to associate negative scores with poor performance, and positive scores with good performance in relation to the implementation of the BMPs. Photographs of each site were taken to confirm the field assessments. The 30 sites were evaluated within 2 days of rainfall events greater than 0.635 cm (0.25 inches) during May 1998.

\section{Results}

Table 2 contains the scores for the 30 sites evaluated. In general, the performance of erosion control measures was poor. With a range of possible scores from -9 to 9 for the nine measures evaluated, a score of zero would indicate average performance. The overall mean for this study was -1.9 , with a range from -7 to 4 . O nly four sites scored above zero.

Of the three categories of measures, slope stabilization BM Ps (mulching, seeding, staging) performed very poorly, with all BMPs receiving highly negative scores. Water management BMPs (buffer strip, filter fence, sediment basin) produced slightly better results, with moderate negatives, and one positive score. Soil stabilization measures were adhered to better-all of the soil stabilization BMPs (grading, access road, spoil piles) achieved a positive score. With respect to individual BM Ps, access roads had the highest mean score (0.37), whereas mulching and seeding received the lowest mean score $(-0.83)$.

Table 3 shows a breakdown of the scoring by site type and stage. Commercial sites in the land clearing stage exhibit the poorest performance with respect to erosion control. Better performance was shown at residential sites in both stages, with the best performance at commercial sites in the foundation/ framing stage. Further research will be required to accurately infer the causes of these differences.

\section{Discussion}

The poor results at a variety of sites indicate a failure to integrate basic scientific or existing technical knowledge of erosion processes and control with policy. A fundamental problem is the lack of basic data about soil, topography, and hydrology at the sites, leading to the incorrect application of BM Ps, such as staging, filter fences, and berms. In addition, the current institutional framework for soil erosion control provides disincentives to monitor local erosion problems.

\section{Soil, Topographic, and Hydrologic Data}

With the stated objective as soil erosion control, it is puzzling why current regulations do not specify the collection of a soil sample at construction sites. Basic information about soil type and texture can help direct specific erosion control measures. For example, the performance of certain geotextiles varies due to the difference in the characteristics of suspended solids associated with different soils (Barrett and others 1998). Two possible reasons for the poor implementation of soil erosion regulations could be the declining $N$ ational Resource Conservation Ser vices staffs, as well as the lack of adequate training that many local planners have in the environmental sciences.

In terms of topography, slope stabilization is critical to erosion control-and recognized by current policy. Even a general evaluation of the landscape that divides it into moraines, outwash plains, and till plains can provide site developers and erosion control personnel with valuable information, such as general drainage characteristics. However, microtopography is not given enough consideration. Specific topographic characteristics observable at regional scales often present themselves as erosion control opportunities at the microscale.

For example, existing micro-scale areas 0.45 ha ( 1 acre) or less in a postglacial landscape may contain multiple sinks for sediment, including natural depres- 
Table 2. Scoring of best management practices

\begin{tabular}{|c|c|c|c|c|c|c|c|c|c|c|c|}
\hline \multirow[b]{2}{*}{$\begin{array}{l}\text { Land } \\
\text { use }\end{array}$} & \multirow[b]{2}{*}{ Stage } & \multicolumn{3}{|c|}{ Slope stabilization } & \multicolumn{3}{|c|}{ Soil stabilization } & \multicolumn{3}{|c|}{ Water management } & \multirow[b]{2}{*}{$\begin{array}{l}\text { Row } \\
\text { total }\end{array}$} \\
\hline & & Mulching & Seeding & Staging & Grading & $\begin{array}{c}\text { Access } \\
\text { road }\end{array}$ & $\begin{array}{l}\text { Spoil } \\
\text { piles }\end{array}$ & $\begin{array}{l}\text { Buffer } \\
\text { strip }\end{array}$ & $\begin{array}{l}\text { Filter } \\
\text { fence }\end{array}$ & $\begin{array}{l}\text { Sediment } \\
\text { basin }\end{array}$ & \\
\hline C & 2 & -1 & -1 & -1 & -1 & 0 & 0 & -1 & -1 & -1 & -7 \\
\hline $\mathrm{C}$ & 1 & -1 & -1 & -1 & 0 & 0 & 0 & -1 & -1 & 1 & -4 \\
\hline C & 2 & -1 & 0 & 1 & 1 & 1 & -1 & 0 & 0 & 1 & 2 \\
\hline C & 2 & 0 & -1 & 0 & 1 & 0 & 1 & 0 & 1 & 1 & 3 \\
\hline $\mathrm{C}$ & 2 & -1 & 0 & 1 & 1 & 1 & 1 & 0 & 0 & -1 & 2 \\
\hline $\mathrm{C}$ & 1 & -1 & -1 & -1 & 1 & 0 & 0 & -1 & -1 & -1 & -5 \\
\hline $\mathrm{C}$ & 2 & -1 & -1 & -1 & 0 & 1 & 0 & 0 & 0 & 1 & -1 \\
\hline $\mathrm{C}$ & 2 & -1 & -1 & -1 & 0 & 1 & 0 & 0 & 0 & 0 & -2 \\
\hline $\mathrm{C}$ & 1 & -1 & -1 & -1 & 0 & 1 & 0 & 0 & -1 & -1 & -4 \\
\hline $\mathrm{C}$ & 2 & -1 & -1 & -1 & 1 & 0 & 0 & 0 & -1 & -1 & -4 \\
\hline $\mathrm{C}$ & 1 & -1 & -1 & -1 & 1 & 1 & 1 & 0 & 0 & 0 & 0 \\
\hline C & 2 & -1 & -1 & -1 & 0 & 0 & 1 & 0 & 0 & -1 & -3 \\
\hline $\mathrm{C}$ & 1 & -1 & -1 & -1 & 0 & 1 & 0 & 0 & -1 & -1 & -4 \\
\hline $\mathrm{R}$ & 2 & -1 & -1 & 1 & 1 & 1 & 0 & -1 & 0 & -1 & -1 \\
\hline $\mathrm{R}$ & 1 & 1 & 0 & 1 & 1 & -1 & 1 & 1 & -1 & 1 & 4 \\
\hline $\mathrm{R}$ & 2 & -1 & -1 & -1 & 0 & 0 & 1 & 1 & 1 & -1 & -1 \\
\hline $\mathrm{R}$ & 2 & -1 & -1 & -1 & 0 & 1 & 0 & 1 & -1 & 1 & -1 \\
\hline $\mathrm{R}$ & 2 & -1 & -1 & -1 & 1 & 0 & 0 & 0 & 0 & -1 & -3 \\
\hline $\mathrm{R}$ & 1 & -1 & -1 & -1 & 0 & 0 & 0 & 1 & 0 & -1 & -3 \\
\hline $\mathrm{R}$ & 2 & -1 & -1 & -1 & -1 & 0 & -1 & 0 & -1 & 1 & -5 \\
\hline $\mathrm{R}$ & 1 & -1 & -1 & -1 & 1 & 1 & 0 & 1 & 1 & -1 & 0 \\
\hline $\mathrm{R}$ & 1 & -1 & -1 & -1 & -1 & -1 & 0 & 0 & 0 & -1 & -6 \\
\hline $\mathrm{R}$ & 2 & -1 & -1 & 1 & -1 & 0 & 1 & 1 & -1 & -1 & -2 \\
\hline $\mathrm{R}$ & 1 & -1 & -1 & -1 & 1 & 1 & -1 & 0 & 0 & 1 & $-\overline{1}$ \\
\hline $\mathrm{R}$ & 1 & -1 & -1 & -1 & 0 & 0 & -1 & 0 & 0 & 1 & -3 \\
\hline $\mathrm{R}$ & 1 & -1 & -1 & -1 & 0 & 0 & -1 & 0 & 0 & -1 & -5 \\
\hline $\mathrm{R}$ & 2 & -1 & -1 & -1 & 1 & 1 & 1 & 0 & -1 & -1 & -2 \\
\hline $\mathrm{R}$ & 1 & -1 & -1 & -1 & 0 & 1 & 0 & -1 & 0 & 1 & -2 \\
\hline $\mathrm{R}$ & 1 & 0 & 0 & -1 & 0 & 0 & 0 & 1 & -1 & 1 & 0 \\
\hline $\mathrm{R}$ & 2 & 0 & 0 & -1 & 1 & 0 & 0 & 1 & 0 & -1 & 0 \\
\hline Columı & otals & -25 & -25 & -19 & 9 & 11 & 3 & 3 & -9 & -9 & -58 \\
\hline Colum & nean & -0.83 & -0.83 & -0.63 & 0.30 & 0.37 & 0.10 & 0.10 & -0.30 & -0.20 & -1.93 \\
\hline
\end{tabular}

$\mathrm{C}=$ Commercial.

$\mathrm{R}=$ Residential .

Table 3. Breakdown of scoring by site type and stage

\begin{tabular}{lccc}
\hline \multirow{2}{*}{ Site type } & $\begin{array}{c}\text { Stage }(1 \text { = land clearing; } \\
\text { 2=foundation/ framing) }\end{array}$ & Range & Mean \\
\hline \multirow{2}{*}{ Commercial } & 1 & $-5,0$ & -3.4 \\
& 2 & $-7,3$ & -1.3 \\
Residential & 1 & $-6,4$ & -1.8 \\
& 2 & $-5,0$ & -1.9 \\
\hline
\end{tabular}

sion storage, root buttresses, small ponds, and wetlands. In addition, lot line margins may exist where the ground is usually rougher and more erosion resistant.

The amount of water storage available from natural depressions is rarely considered. On a 0.45 -ha lot, a natural depression $30 \mathrm{~cm}$ deep ( $1 \mathrm{ft}$ ) covering an area of $83.6 \mathrm{~m}^{2}\left(900 \mathrm{ft}^{2}\right)$ can instantaneously store $25.5 \mathrm{~m}^{3}$
(6733 gals) of water. Assuming modest infiltration of $5 \mathrm{~cm}$ ( 2 in) per day for the same size depression, the potential storage increases by $4.2 \mathrm{~m}^{3}$ (1122 gals). On developments with many lots, or large-scale commercial/ industrial sites, the amount of natural depression storage can be substantial.

Hydrologic data necessary for site-specific erosion control include seasonal precipitation patterns and the characteristics of proximate surface water and groundwater resources. Erosion control measures should accommodate seasonal precipitation magnitude and frequency characteristics. At large-scale projects, this can be accomplished by developing the less erosive portions of sites ( staging) during the seasonal periods tending to exhibit the highest precipitation intensity, duration, and frequency. The more erodible sections of these large construction sites can be developed during gener- 


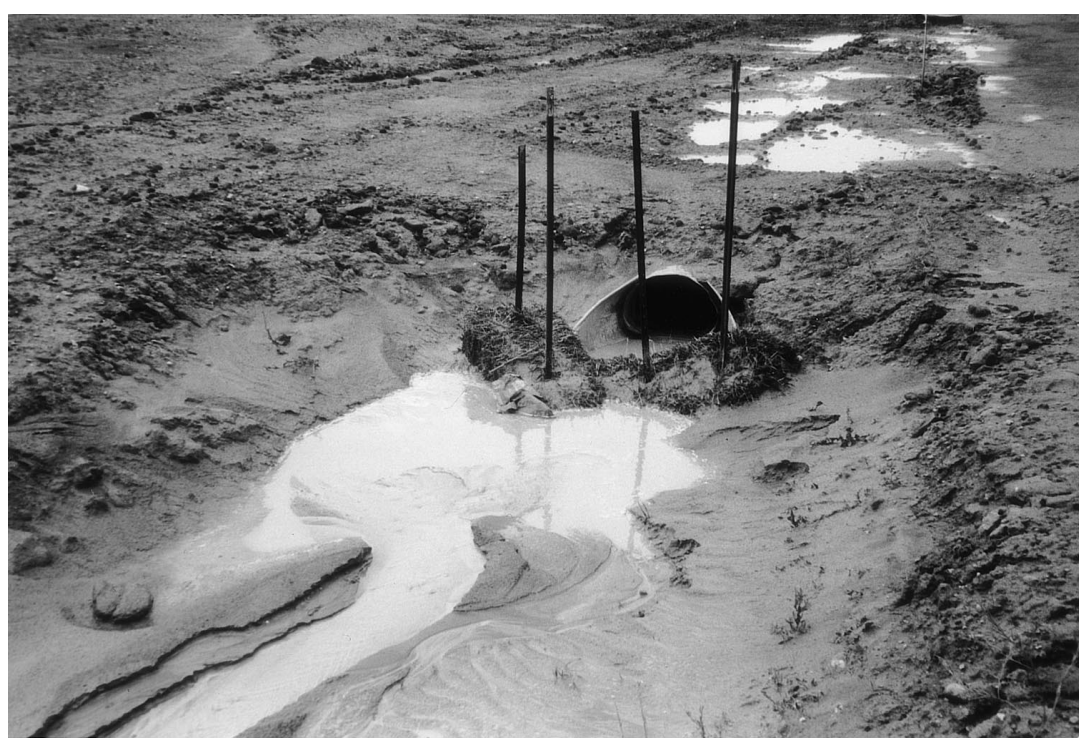

Figure 3. Improper water management.

ally dry periods. At smaller sites, special attention should be given to "roughing up" the soil just before quitting time, as most of the intense rainstorms associated with large urban microclimates occur late in the afternoon (Changnon 1978) .

Precipitation characteristics should also influence the BMP inspection protocol. Inspection schedules should include at least one precipitation event-related visit for each site, thus enabling an evaluation of the BM Ps' effectiveness when they are put to their true test.

With respect to proximate water resources, overland flow is the dominant source of runoff for peak events in small watersheds (Chow 1988). Since new development on the urban fringe often focuses in the upper parts of relatively small drainage networks, the local streams often suffer from increased flooding. Thus, erosion control measures must consider the smallest drainage unit, and account for these surface flows. Special consideration should be given to road placement in developing areas, which should be designed so as to not join partial areas of runoff.

Figure 3 illustrates an erosion problem found at many construction sites. Roads are built early in the land clearing stage to enable construction vehicle access to the site. During this time, storm drains are also put into place. This is an inherent problem with construction phasing, and any approach should consider isolating the on-site runoff. With proper water management, either through the use of sumps or detention basins, the sediment-laden runoff from the roads and unstabilized soil will not clog the storm drains. O ther wise, extra maintenance may be required, or in extreme cases damage the pipes.

\section{Incorrect Application of BMPs}

Figure 4 shows the rill erosion caused by inadequate slope stabilization. Current grading practice has most house lots sloping down to the street to facilitate runoff into a nearby storm drain. Some of this water can be infiltrated on site to reduce stormwater volumes. Developers and plannersfor new construction projects should consider the placement of slight depression storage areas within the site to enable the detention of water both during and after construction is completed.

Berm creation at the development margins and the proper placement of filter fences can be an effective erosion control mechanism. The objective is to create berms, which allow filter fences to function without bearing heavy sediment loads (Figure 5). Placement of the fences on level areas near the berm eliminates the overloads created by downslope water and sediment transport. The load on the fences often causes them to collapse- a condition found at many of the sites investigated for this study.

\section{Disincentives for Erosion Control}

Clearly, developers are not following the BM P recommendations, and/ or the law is not being enforced. This underscores problems in the existing institutional framework for local erosion control. This problem is nationwide and not limited to Michigan.

Erosion and sedimentation are key contributors to water quality problems, but historically the legal and institutional linkages necessary to manage these problems jointly have been fuzzy. Erosion control became a federal goal with the passage of the Soil Conservation 
Figure 4. Inadequate slope stabilization.
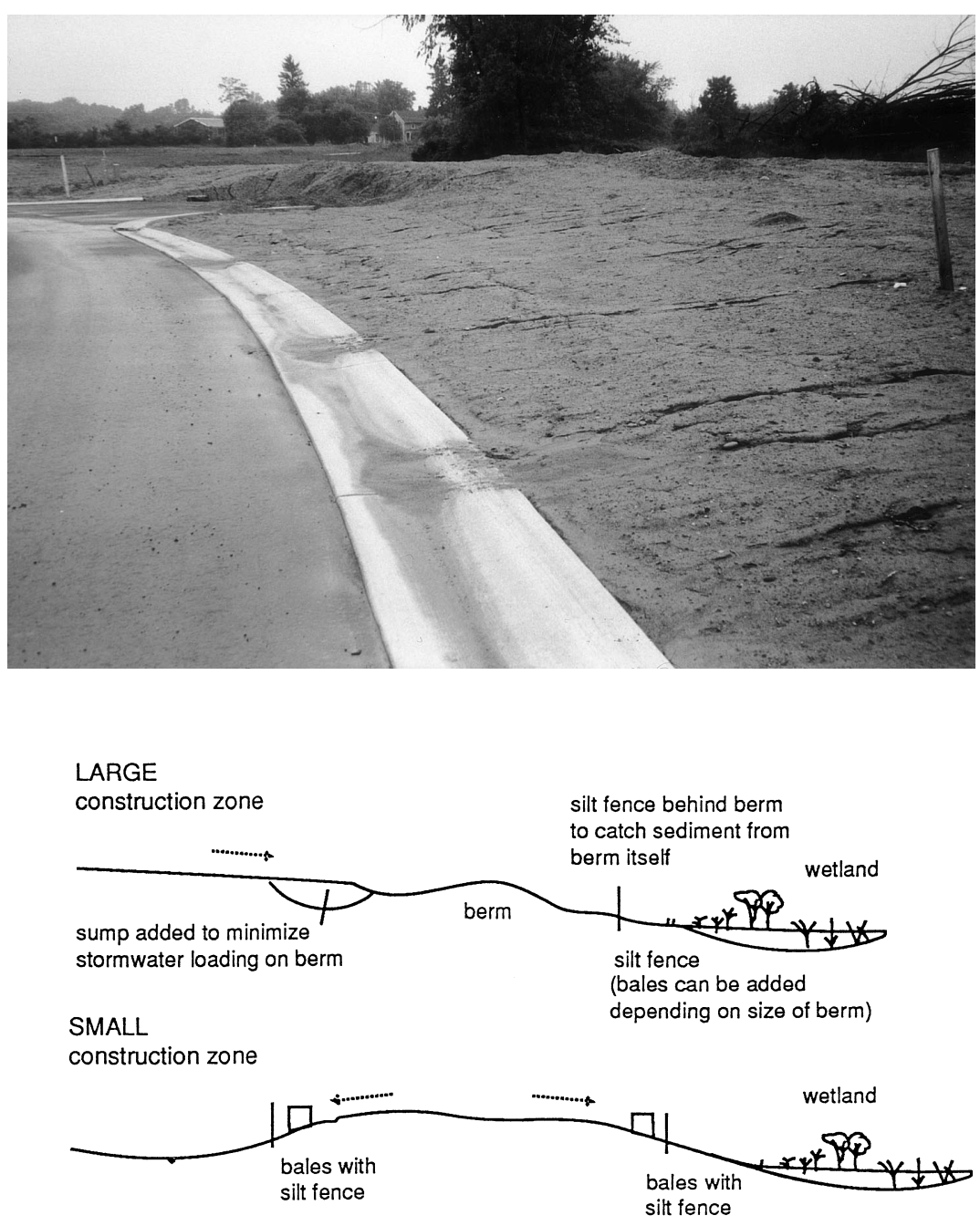

SMALL

construction zone with setback from wetland

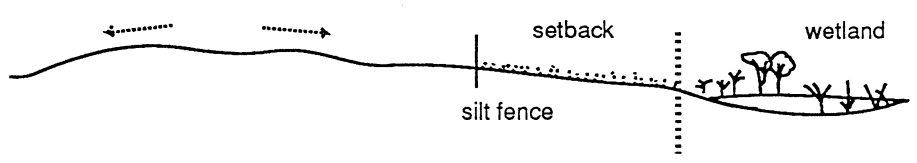

Figure 5. Sediment control: construction sites (after Marsh [ 1998]).

............ direction of overland flow

Act of 1935. When thislaw was enacted during the Great Depression, many other goals besides soil conservation (e.g., unemployment and price stabilization) were also concerns. As noted by Steiner (1990) the relationship between soil conservation and other goals-including water management-was not readily apparent.

After the postwar economic growth of the 1950s, the nation experienced increasing signs of environmental damage-exemplified in the late 1960s by the Santa Barbara oil spill and the fire within the Cuyahoga River in O hio. Response to the geographic scale and severity of these events widened the scope of environmental policy and institutional involvement, leading to the enactment of the National Environmental Policy Act of 1969 and the establishment of the Environmental Protection Agency in 1970. An explicit linkage between soil erosion and water quality was established by the passage of the 1972 Clean Water Act (CWA), which incorporated erosion control as part of its nonpoint pollution mitigation strategy. This was embodied in Section 208 of the CWA, which promoted voluntary regional land use planning efforts for improving water quality. However, the voluntary aspect of compliance, coupled with the traditionally high resistance to centralized authority 
among the U.S. populace, hindered the implementation of this legislation.

Local communities reacted negatively to the "command and control" efforts by the federal government under Section 208 to impose local land use decisions. These planning efforts were usually housed within regional councils of government, and most failed. Communities were eager to assume local control of their land use decisions (Malone 1990). Many states already had erosion control laws, and were allowing communities to adopt them locally "by reference."

Aspublic concern about the environment rose, more local ordinances were adopted to address specific problems, such as wetland preservation and storm water management. This specialization often blurred the institutional recognition of the linkage between erosion control measures, storm water management, and other watershed-wide environmental processes.

One example of an institutionally unrecognized linkage between erosion control and storm water management exists at the microtopographic scale with respect to source control. In many communities, lotgrading practices continue, which facilitate rapid drainage into the street. This practice accelerates erosion. Keeping water on site and moving vertically into ground water prevents excess runoff and its sediment load from reaching the storm sewer and the nearest water body.

Accompanying local ordinance specialization was the loss of federal funding for local water projects during the 1980s. Communities were now forced to focus on water management at the local scale. This inhibited watershed-wide approaches, which, when coupled with the process of ordinance specialization, led to a separation of land and water management at the local institutional scale. For instance, many communities organized wetland committees to oversee their wetland ordinances.

Even the separation of nonpoint pollution control nomenclature on the basis of location may be affecting local erosion control efforts. Urban nonpoint pollution is often referred to as stormwater runoff, and in rural areas it is still called nonpoint pollution. This has the effect of obscuring urban erosion control as part of a comprehensive approach to watershed management in watersheds that often combine rural and urban land uses.

\section{Conclusions}

This research provides a method for quantifying the effectiveness of erosion control programs at specific scales. An evaluation of multiple erosion control measures was conducted at 30 construction sites in various stages of development using BMPs applicable to three general categories. The poor performance in all categories of erosion control reflects a failure to integrate science and policy. O ne fundamental problem obser ved was the lack of basic data about soil, topography, and hydrology at the sites, leading to the incorrect application of BMPs. Another problem is the current institutional framework, which provides disincentives to mitigate erosion.

Scientific approaches to erosion control at construction sites must account for climatic tendencies and take advantage of the inherent capabilities of the landscape. Application of BMPs should take advantage of current science, with rigorous consideration given to the placement and timing of control and monitoring measures.

Bridging the science-policy gap will require an overhaul of the institutional framework for environmental policy at local and regional geographic scales. Local erosion control must be incorporated into a comprehensive watershed management plan with institutional forms having legal enforcement capability. These institutional forms should exist at the watershed scale to properly accommodate the geographic scale of the physical processes involved. The placement of soil erosion LEAs within county government creates a mismatch between the scale of this institutional form and the watershed-wide process scale of erosion, as well as with other watershed scale processes, such as stormwater runoff. As a result, jurisdictional disputes are more likely to develop.

\section{Acknowledgments}

The author thanks research assistant Brian Moffett for his data collection efforts, and Professor William M. Marsh at the University of Michigan-Flint for his helpful comments about the manuscript.

\section{Literature Cited}

Barrett, M. E., J. F. Malina, Jr., R. J. Charbeneau, and G. H. Ward. 1995a. Water qual ity and quantity impacts of high way construction and operation: summary and conclusions. Center for Research in Water Resources Technical Report 266, University of Texas, Austin, TX.

Barrett, M. E., J. E. Kearney, T. G. McCoy, J. F. Malina, Jr., R. J. Charbeneau, and G. H. Ward. 1995b. An evaluation of the performance of temporary sediment controls. Center for Research in Water Resources Technical Report 261, University of Texas, Austin, TX.

Barrett, M. E., J. F. Malina, Jr., and R. J. Charbeneau. 1998. An evaluation of geotextiles for temporary sediment control. Water Environ ment R esearch 70:283-290.

Booth, D. B. 1990. Stream channel incision following drainage basin urbanization. Water R esou rces Bulletin 26:407-417. 
Changnon, S. 1978. U rban effects on severe local storms at St. Louis. Journal of Applied M eteorology 17:578-586.

Chow, V. 1988. Applied hydrology. McGraw-H ill, New York, NY.

Earle, G. H. 1972. Soil survey of Lapeer County, Michigan. US Department of Agriculture, Soil Conservation Service, USGPO, Washington, DC.

Engel, R. 1977. Soil survey of Washtenaw County, Michigan. US Department of Agriculture, Soil Conservation Service, USGPO, Washington, D.C.

Feenstra, J. 1982. Soil survey of O akland County, Michigan. US Department of Agriculture, Soil Conservation Service, USGPO, Washington, D.C.

Graf, W. 1975. The impact of suburbanization on fluvial geomorphology. Water R esou rces R esearch 11:690-692.

Holcomb, S. 1993. Soil survey of Genesee County, Michigan. US Department of Agriculture, Soil Conservation Service, USGPO, Washington, D.C.

Horner, R. R., J. Guedry, and M. H. Kortenhof. 1990. Improving the cost effectiveness of highway construction site erosion and pollution control. Washington State Transportation Center, Washington State Department of Transportation, Seattle, WA.

I aquinta, J. 1994. Soil survey of Saginaw County, Michigan. US Department of Agriculture, Soil Conservation Service, USGPO. Washington, D.C.

Knowen, N. 1990. Silt fences to control sediment movement on construction sites. Report M AT-90-03, Research Development Branch Ontario Ministry of Transportation, Downsview, O ntario, Canada.
Malone, L. A. 1990. Environmental regulation of land use. Clark Boardman, N ew York, NY.

Marsh, W. M. 1998. Landscape planning, 3d ed. Wiley, New York, NY.

MCLA. 1998. Michigan compiled laws annotated. Act 347 of 1972, West Publishing, St. Paul, MN .

MDEQ (Michigan Department of Environmental Quality). 1992. Guidebook of best management practices for Michigan's watersheds. MDEQ, Lansing, MI.

MDNR (Michigan Department of Natural Resources). 1988. Michigan's nonpoint pollution control management plan. MDNR, Lansing, MI.

Mertes, J. D. 1989. Trends in governmental control of erosion an sedimentation in urban development. Journal of Soil and Water Conservation 44:550-554.

Pimentel, D., C. Harvey, P. Resosudarmo, K. Sinclair, D. Kurz, M. McNair, S. Crist, L. Shpritz, L. Fitton, R. Saffouri, and R. Blair. 1995. Environmental and economic costs of soil erosion and conservation benefits. Science 267:1117-1123.

Scheuler, T. R., and J. Lugbill. 1989. Performance of current sediment control measures at Maryland construction sites. Prepared for the Maryland Department of the Environment by the Metropolitan Washington Council of Government, Washington, DC.

Steiner, F. R. 1990. Soil conservation in the United States. Johns Hopkins U niversity Press, Baltimore, MD.

Wolman, M. G., and A. P. Schick. 1967. Effects of construction on fluvial sediment, urban and suburban areas of Maryland. Water Resou rces Research 3:451-464. 